\title{
Recycling of Waste Materials for Stabilizing Ash from Co-Combustion of Municipal Solid Wastes with an Olive By-Product: Soil Leaching Experiments
}

\author{
Despina Vamvuka *, Stelios Alexandrakis, George Alevizos and Antonios Stratakis
}

School of Mineral Resources Engineering, Technical University of Crete, Akrotiri Campus, 73100 Hania, Greece; ste.alexandrakis@gmail.com (S.A.); alevizos@mred.tuc.gr (G.A.); astratak@mred.tuc.gr (A.S.)

* Correspondence: vamvuka@mred.tuc.gr

Received: 21 April 2020; Accepted: 14 May 2020; Published: 19 May 2020

check for updates

\begin{abstract}
In the context of the current environmental policies of the European Union promoting the recycling and reuse of waste materials, this work aimed at investigating the environmental impact of ashes produced from the co-combustion of municipal solid wastes with olive kernel in a fixed bed unit. Lignite fly ash, silica fume, wheat straw ash, meat and bone meal biochar, and mixtures of them were used as stabilizing ash materials. All solids were characterized by physical, chemical and mineralogical analyses. Column leaching tests of unstabilized and stabilized ash through a quarzitic soil were conducted, simulating field conditions. $\mathrm{pH}$, electrical conductivity, chloride, sulphate and phosphate ions, major and trace elements in the leachates were measured. The results showed that alkaline compounds were partially dissolved in water extracts, increasing their $\mathrm{pH}$ and thus decreasing the leachability of heavy metals from the ash. Cr leached from unstabilized ash reached a hazardous level. Upon the stabilization of ash, the concentrations of heavy metals in the extracts were reduced between $9 \%$ and $100 \%$, and were below legislation limits for disposal, apart from Cr. The latter was achieved only when meat and bone meal biochar was used as stabilizer. Entrapment of ash elements was assigned to the amorphous silica and to the phosphates of the stabilizing materials, as well as complexed silicates formed during the process.
\end{abstract}

Keywords: municipal solid wastes; ash; stabilization; soil leaching

\section{Introduction}

Due to the continuous increase in energy demand and the environmental impact of fossil fuels, policies of European Union (EU) and most countries in the world are fostering the use of renewable energy for power generation and an increased share of biomass fuels [1]. Municipal solid wastes (MSW), produced in large quantities across the world, are considered as biomass fuels. Their thermal treatment reduces disposal volume in landfills and cost, destroying hazardous constituents related to pathogens and other pollutants and allows for energy recovery, increasing economic returns to rural communities. However, the heterogeneity and variable composition of such wastes, unlike other biomass materials, may pose serious limitations in energy systems and create technical and environmental barriers $[2,3]$. Accordingly, their blending with higher quality woody residues-such as agricultural wastes, which are abundantly found at low or no cost, especially in South Europe-seems a promising solution. The Waste Framework Directive of the EU has already set the hierarchy of the waste policy and management for recycling and reuse [4].

Consequently, the increase in incineration or co-firing technologies of wastes will result in the production of huge amounts of ashes (about $25 \%$ of mass input) with different characteristics, which may create operational or environmental problems and, on the other hand, determine the 
potential valorification of these ashes in various applications $[2,5,6]$. Some minerals in ashes may have a vitalizing effect upon recycling to soils [7], or may cause eutrophication problems. However, most heavy metals, being toxic, could seriously threaten the health of humans, animals and plants [8]. Therefore, proper management of ashes is of great importance for the environmental monitoring and protection, or their utilization, taking into account the increased bioenergy demand in the forthcoming years.

Different treatment technologies have been proposed for the stabilization of ashes, including separation, solidification, chemical stabilization and thermal processes. Separation methods intend generally to extract by water leaching soluble salts from the waste, but they require post-treatment of waste water. Thermal treatment, such as vitrification, sintering and melting, is energy consuming and may cause equipment corrosion due to high temperatures, and secondary pollution through the release of volatile metals. Solidification with cement/lime-based materials, although a mature technology, is limited by the increase in mass and volume of the waste, leading to the extra cost of transportation and disposal [9-14]. Chemical stabilization treatment has shown satisfactory results for the immobilization of toxic metals in ashes, using a variety of chemical compounds, such as sulfides [15], phosphates [10,11], silicates [11] and chelating agents [11,13,16].

However, current environmental policies of EU foster a circular economy, promoting the recycling and reuse of waste materials. Accordingly, several waste by-products have been used as stabilizing materials. Recently, a process based on a mixture of flue gas desulphurization residue, coal fly ash and an amorphous silica source, such as silica fume or rice husk ash, was developed for the stabilization of MSW fly ash, particularly of heavy metals $\mathrm{Pb}$ and $\mathrm{Zn}[9,17,18]$. The mechanism was explained by the sorption of metal ions on silica surface. Flue gas desulphurization residue and coal fly ash were added to improve some concrete characteristics. Rice husk ash, possessing pozzolanic properties, was also used in another study for partial replacement of cement for the immobilization of $\mathrm{Pb}$ and $\mathrm{Cu}$ [19]. Different sources of amorphous silica, such as sewage sludge ash [20] and MSW bottom ash [21] were also employed for the stabilization of MSW fly ash, through the promotion of carbonation and pozzolanic reactions.

Several standard leaching procedures have been applied, to assess the risk from disposal of chemically or physically treated MSW fly ashes (TCLP, EN12457/t-4, DIN38414-S4, etc.) $[10,22]$. However, these tests cannot provide sufficient information for landfill applications and may give misleading estimates of environmental impact [10]. Column leaching experiments, simulating field conditions for disposal of MSW ashes, have not been performed so far. Furthermore, there is lack of data on the leaching behaviour of bottom ashes produced from co-firing agricultural with MSW wastes in fixed bed units.

In a previous work in our laboratory [23], fixed bed ash, generated by the co-combustion of MSW and olive kernel (OK), was found to present a greater extractability of toxic elements upon leaching, than fluidized bed fly ash of the same feedstock. In view of the need, as previously discussed, to use sustainable materials and economic inertilization procedures, minimizing energy and emissions, the current study aimed at utilizing only waste materials for stabilizing MSW/OK ash, such as lignite fly ash, silica fume, wheat straw ash, meat and bone meal (MBM) biochar, or mixtures of them. Lignite fly ash, produced by many power plants in Europe, has not been used before as stabilizing agent. Furthermore, wheat straw, an abundant agricultural residue, has not been adopted as a silica source. Finally, MBM-generated in huge amounts from food processing industries worldwide, treated thermally to destroy pathogens and gain added-value products-was investigated for the first time for its potential to stabilize waste biomass ashes. The methodology employed consisted of physical, chemical and mineralogical characterization of all materials involved, followed by column leaching tests of unstabilized and stabilized ash through soil and subsequent measurements of ions and metals in the leachates. 


\section{Materials and Methods}

\subsection{Origin and Preparation of Ash and Stabilizers}

The ash used for the leaching experiments of this study was produced form co-combustion tests of MSW with OK at a mixing ratio of 10:90 by weight, in a fixed bed unit. The urban waste was collected form the solid wastes management company DEDISA of the region of Chania, Crete, from representative samples during a whole year. OK was provided form a local oil factory. Raw materials were air dried, riffled, homogenized and ground to a particle size of 1-3 $\mathrm{mm}$, before being used for the combustion test. The system (ID $=70 \mathrm{~mm}, \mathrm{H}=2 \mathrm{~m}$ ) has been described in detail in a previous work by the authors [24]. Feeding rate was $0.72 \mathrm{~kg} / \mathrm{h}$, excess air ratio 1.4 and maximum combustion temperature $845^{\circ} \mathrm{C}$.

As stabilizers, the following materials were used: (i) a lignite fly ash from the power plant of Melitis in Florina, North Greece, (ii) silica fume, a fine non-crystalline silica with mean particle size $0.11 \mu \mathrm{m}$ and specific surface area $25 \mathrm{~m}^{2} / \mathrm{g}$, by-product of elemental silicon production, provided by Elkem company, Norway, (iii) wheat straw ash obtained from the area near the power plants in North Greece and (iv) a $550{ }^{\circ} \mathrm{C}$ produced biochar from MBM, provided from a swine breeding factory in Crete (equipment for biochar production was presented in a previous investigation [25]). Stabilizers were blended with the ash sample at weight percentages $10 \%$ or $20 \%$ and the mixtures were wetted with deionized water at a liquid/solid ratio of about 0.3 and stirred for $1 \mathrm{~h}$ in a laboratory mixer at $100{ }^{\circ} \mathrm{C}$, according to the method proposed by [17]. After homogenization, the samples were left at room temperature for 1 month, thus allowing the stabilization reactions to complete and water to totally evaporate.

\subsection{Leaching of Raw and Stabilized Ash through the Soil}

Sampling of soil was conducted systematically, following the method of rectangular grid, from the top $30 \mathrm{~cm}$ of the area next to DEDISA company, where possible ash deposition is about to occur. After being sieved to a particle size of $<2 \mathrm{~mm}$, and analyzed for its proportions in sand, silt and clay, the soil was mixed with each ash material at proportions 95:5, to maintain compatibility with field conditions.

Vertical glass columns with and ID of $4.5 \mathrm{~cm}$ and a height of $50 \mathrm{~cm}$ were adopted for the tests, in order to produce an estimate of long-term leaching behaviour. Each column was fitted with fiberglass into the drain opening and a valve at the base to control leachate collection. About $180 \mathrm{~g}$ soil ash mixture was packed into the column and saturated with de-ionized water. Leaching was initiated by percolating purified water continuously, keeping at the same time the hydraulic head constant. The amount of water was chosen to correspond to the average annual quantity of rainfall in the area of Chania, Crete $(\sim 620 \mathrm{~mm})$. Each column effluent was collected in glass flasks, filtered through micropore membrane filter and the $\mathrm{pH}$ and electrical conductivity (EC) of each extract were measured. Liquid samples were kept in the refrigerator and prepared for the chemical analyses within a few days. Measured parameter values were the average from two experiments for each case (error $\pm 2.5 \%$ ).

\subsection{Characterization of Solids and Liquid Analyses}

Mineral phases of solid materials involved were detected by an X-ray diffractometer (XRD), model D8 Advance of Bruker AXS. The scans were performed between 2 and $702 \theta^{\circ}$, with increments of $0.02^{\circ} / \mathrm{s}$, applying $\mathrm{Cu} \mathrm{K} \alpha$ radiation. The database JCPDS, in conjunction with software DIFFRAC plus Evaluation, was used for identification of minerals and data processing.

A spectrophotometer (Spectrum 1000, Perkin Elmer) was employed for the Fourier Transform Infrared (FTIR) analysis of the samples, in the range of $4000-400 \mathrm{~cm}^{-1}$ wavenumber, at a resolution of $4 \mathrm{~cm}^{-1}$. The samples were pelletized after being mixed with $\mathrm{KBr}$ at a ratio of $1 / 100 w / w$.

Major and trace metal analyses of solids and liquids were conducted by an inductively coupled plasma mass spectrometer, model ICP-MS 7500cx of Agilent Technologies, assisted by microwave digestion with $\mathrm{HNO}_{3}$ acid, in Anton Paar Multiwave 3000 oven. Phosphorous in solids was determined, 
after acid digestion with $\mathrm{HCl}, \mathrm{HF}$ and $\mathrm{HNO}_{3}$ acids and heating in a water bath at $80^{\circ} \mathrm{C}$, with a UV-VIS spectrophotometer type DR/4000V of Hach. For silicon measurement, fusion of each sample with $\mathrm{Li}_{2} \mathrm{~B}_{4} \mathrm{O}_{7}$ at $980^{\circ} \mathrm{C}$ was conducted, followed by digestion with $\mathrm{HNO}_{3}$ acid and analysis in an atomic absorption spectrometer (AAS) type Analyst-100 of Perkin Elmer.

$\mathrm{pH}$ and EC were measured using a bench top meter precision pH/Ortmeter 920 and a Hanna bench conductivity EC215, respectively. For solid samples, the solid-to-liquid ratio was 1:5. The cation exchange capacity (CEC) was determined according to the ammonium acetate $\left(\mathrm{NH}_{4} \mathrm{OAC}\right)$ extraction method [26]. The concentrations of chloride, sulphate and phosphate ions in the leachates were derived through the use of a UV-VIS spectrophotometer model Smart 3 of LaMotte, by applying the argentometric method 3693-SC, the barium chloride method 3665-SC and the vanadomolybdophosphoric acid method 3655-SC.

\section{Results and Discussion}

\subsection{Physical and Chemical Properties of Soil and Ash Samples}

The mineral phases of the soil and ash materials are listed in Table 1. As can be seen, the soil was of quarzitic origin (sand $=42.5 \%$, silt $=37.2 \%$, clays $=20.3 \%$ ), containing small amounts of muscovite and clinochlore. OK/MSW ash was dominated by quartz, $\mathrm{Ca}$ and K-based minerals. Ca was bound in sulphates (anhydrite, most probably formed by dehydration of gypsum, as the $\mathrm{SO}_{2}$ concentration of flue gas was found to be extremely low), carbonates (calcite, dolomite, fairchildite), phosphates (hydroxylapatite, possibly associated with the use of fertilizers such as $\mathrm{NH}_{4} \mathrm{H}_{2} \mathrm{PO}_{4}$ during the cultivation of olive trees [24]) and to a small extent in silicates (monticellite). Potassium was incorporated in sulphates (arcanite, aphthitalite), chlorides (sylvite), carbonates (fairchildite) and in small amounts in clays, such as microcline and muscovite. $\mathrm{Mg}$ was also present in periclase and magnesite, while Fe was detected in the form of srebrodolskite.

Table 1. Physical and chemical properties of soil and ash.

\begin{tabular}{|c|c|c|}
\hline & \multicolumn{2}{|c|}{ Sample } \\
\hline & Soil & OK/MSW Ash \\
\hline $\mathrm{pH}$ & 7.1 & 13.0 \\
\hline $\mathrm{EC}(\mathrm{mS} / \mathrm{cm})$ & 0.02 & 1.5 \\
\hline CEC (meq/100g) & 0.76 & 0.01 \\
\hline \multicolumn{3}{|l|}{ Mineral phases } \\
\hline Calcite $\mathrm{CaCO}_{3}$ & & + \\
\hline Quartz $\mathrm{SiO}_{2}$ & +++ & ++ \\
\hline Anhydrite $\mathrm{CaSO}_{4}$ & & ++ \\
\hline Dolomite $\mathrm{CaMg}\left(\mathrm{CO}_{3}\right)_{2}$ & & + \\
\hline Arcanite $\mathrm{K}_{2} \mathrm{SO}_{4}$ & & ++ \\
\hline Periclase $\mathrm{MgO}$ & & + \\
\hline Fairchildite $\mathrm{K}_{2} \mathrm{Ca}\left(\mathrm{CO}_{3}\right)_{2}$ & & + \\
\hline Sylvite $\mathrm{KCl}$ & & + \\
\hline Hydroxyapatite $\mathrm{Ca}_{5}\left(\mathrm{PO}_{4}\right)_{3}(\mathrm{OH})$ & & + \\
\hline Microcline $\mathrm{KAlSi}_{3} \mathrm{O}_{8}$ & & + \\
\hline Aphthitalite $\mathrm{NaK}_{3}\left(\mathrm{SO}_{4}\right)_{2}$ & & + \\
\hline Magnesite $\mathrm{MgCO}_{3}$ & & + \\
\hline Muscovite $\mathrm{KAl}_{2}\left(\mathrm{Si}_{3} \mathrm{AlO}_{10}\right)(\mathrm{OH})_{2}$ & + & + \\
\hline Monticellite $\mathrm{Ca}(\mathrm{MgFe}) \mathrm{SiO}_{4}$ & & + \\
\hline Srebrodolskite $\mathrm{Ca}_{2} \mathrm{Fe}_{2} \mathrm{O}_{5}$ & & + \\
\hline $\begin{array}{c}\text { Clinochlore } \\
(\mathrm{Mg}, \mathrm{Fe})_{5} \mathrm{Al}\left(\mathrm{Si}_{3} \mathrm{Al}\right) \mathrm{O}_{10}(\mathrm{OH})_{8}\end{array}$ & + & \\
\hline
\end{tabular}

Table 1 indicates that the $\mathrm{pH}$ of the soil was neutral, while that of ash was highly alkaline, due to great amounts of alkali in its content, as shown above, principally $\mathrm{Ca}$ and $\mathrm{K}$. The $\mathrm{EC}$, which is used to estimate the quantity of total dissolved salts, was very low in both samples. The high $\mathrm{pH}$ and the low salinity of present materials are expected to have a positive effect on the leachability of the various 
species from the soil. On the other hand, the CEC of soil, as seen in Table 1, was also very low, implying the weak ability of the soil to adsorb cations and retard or prevent their leaching.

The concentrations of major elements in ash sample are compared in Figure 1a. The high levels of $\mathrm{Ca}, \mathrm{K}$ in $\mathrm{OK} / \mathrm{MSW}$ ash are consistent with the mineralogical analysis. For soil (not shown in the graph due to difference in scale), the most abundant element was $\mathrm{Si}(173.7 \mathrm{~g} / \mathrm{kg})$ incorporated in quartz, in accordance to the XRD analysis. Fe $(23.8 \mathrm{~g} / \mathrm{kg})$ and $\mathrm{Al}(16.9 \mathrm{~g} / \mathrm{kg})$ were associated with clinochlore and muscovite minerals, as previously shown. As concerns trace elements, Figure $1 \mathrm{~b}$ shows that the ash was rich in $\mathrm{Mn}$ and contained similar amounts of $\mathrm{Cr}$ and $\mathrm{Pb}$. A previous study by the authors [2] reported elevated amounts of $\mathrm{Cr}$ and $\mathrm{Pb}$ in MSW ash. OK/MSW ash was also enriched in $\mathrm{Sr}$. Toxic heavy metals $\mathrm{As}, \mathrm{Cd}, \mathrm{Hg}$ and Co were omitted from the graphs, as they ranged from $<0.4 \mathrm{ppb}$ to $9 \mathrm{ppm}$. All measured values were comparable to those reported in literature $[2,24,27]$ and below the upper limit for disposal in landfills, set by EU directives (for $\mathrm{Cr} 500 \mathrm{mg} / \mathrm{kg}$, for Cu $1750 \mathrm{mg} / \mathrm{kg}$, for Ni $400 \mathrm{mg} / \mathrm{kg}$, for Zn $4000 \mathrm{mg} / \mathrm{kg}$ and for Pb $1200 \mathrm{mg} / \mathrm{kg}$ ) [28].
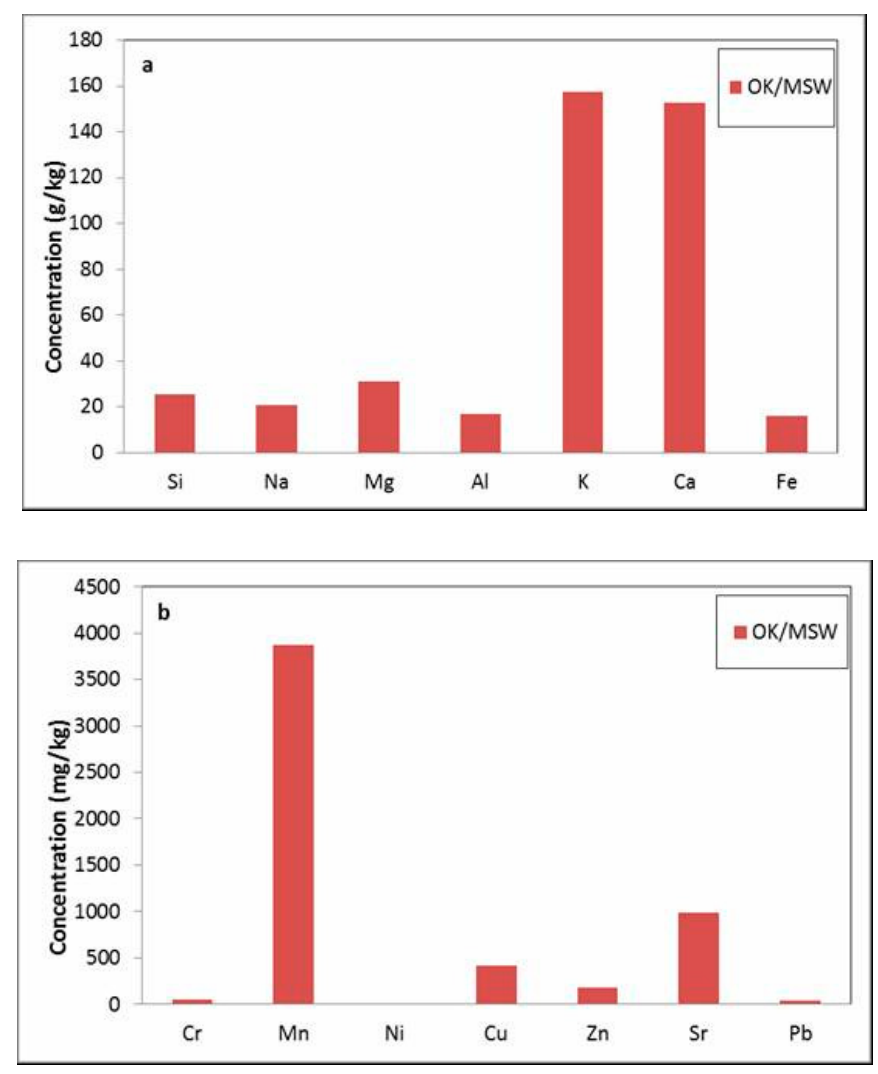

Figure 1. Concentration of (a) major and (b) trace elements in OK/MSW ash.

\subsection{Leachability of the Various Species from the Soil/Ash Sample}

The variation of $\mathrm{pH}$ and $\mathrm{EC}$ with leaching time, as well as the concentrations of chloride and sulphate ions in the extracts collected from the leaching of OK/MSW ash through the soil, are represented in Table 2. As can be observed, $\mathrm{pH}$ increased gradually from 8 to 8.7 with time, implying some dissolution of the alkaline compounds contained in the ash (XRD analysis in Table 1), such as carbonates of $\mathrm{K}, \mathrm{Ca}$ and $\mathrm{Mg}$. In contrast, the EC of the water extracts, which was anyway very low, dropped to almost zero values after the release of soluble salts in the first leachate. Both $\mathrm{pH}$ and EC are known $[19,22,25,29]$ to affect the mobility of the various ions and metals through soils.

The chlorine ions seen in Table 2 were very low and were attributed to soluble sylvite in $\mathrm{OK} / \mathrm{MSW}$ ash. On the other hand, the concentration of sulphate ions in the leachates was considerable, due to the sulphate compounds in the ash anhydrite, arcanite and aphthitalite, as previously discussed 
in the XRD analysis. Phosphate ions were not measurable in the water extracts, as they were strongly correlated to the mineral phase hydroxyapatite in ash. A direct comparison of present values with those of other studies is difficult, because of the very few data reported, as well as the different raw materials and leaching conditions. Some values measured in liquid extracts from MSW ashes were 670-10,330 mg/L [21], $2540 \mathrm{mg} / \mathrm{L}$ [12], $6212 \mathrm{mg} / \mathrm{L}$ [10] for chlorine and $3060 \mathrm{mg} / \mathrm{L}$ [10] for sulphate ions, i.e., much higher than current results. The legal limits for non-hazardous waste landfills are $1500 \mathrm{mg} / \mathrm{L}$ and $2000 \mathrm{mg} / \mathrm{L}$, respectively [30].

Table 2. Variation of $\mathrm{pH}, \mathrm{EC}$ and ions with time in the leachates of soil/ash.

\begin{tabular}{ccccc}
\hline Leaching Time (min) & $\mathbf{p H}$ & $\mathbf{E C}(\mathbf{m S} / \mathbf{c m})$ & $\mathbf{C l}^{-} \mathbf{( m g / L )}$ & $\mathbf{S O}_{4}{ }^{2-} \mathbf{( m g / L )}$ \\
\hline 20 & 7.97 & 3.30 & 51.8 & 402 \\
52 & 8.66 & 0.73 & 15.8 & 154 \\
87 & 8.67 & 0.29 & 6.0 & 52 \\
128 & 8.69 & 0.19 & 5.2 & 37 \\
174 & 8.72 & 0.15 & 4.0 & 14 \\
\hline
\end{tabular}

The variation of the most mobile alkali cations, among major elements, with leaching time is illustrated in Figure 2a. Na, which is a strongly hydrated cation, and was present in aphthitalite, was extracted in higher amounts, followed by $\mathrm{K}$ and $\mathrm{Mg}$. $\mathrm{K}$ was bound in soluble forms of chlorides, sulphates and carbonates, such as sylvite, arcanite, aphthitalite and fairchildite, while Mg in magnesite, dolomite and magnesium hydroxide formed.

The concentrations of heavy metals measured in the leachates were very low (apart from $\mathrm{Cr}$ ) and did not exceed legal limits (for As $0.2 \mathrm{mg} / \mathrm{L}$, for Cr $1 \mathrm{mg} / \mathrm{L}$, for Cu $5 \mathrm{mg} / \mathrm{L}$, for Ni $1 \mathrm{mg} / \mathrm{L}$, for Pb $1 \mathrm{mg} / \mathrm{L}$, for Zn $5 \mathrm{mg} / \mathrm{L}$ ) stipulated by EU Directives for waste landfilling [30,31]. Ni and Cu showed the lowest mobility, reaching levels of $\sim 2-38 \mu \mathrm{g} / \mathrm{L}$ in the leachates. $\mathrm{Mn}, \mathrm{Zn}$ and As were extracted in moderate amounts between 8 and $140 \mu \mathrm{g} / \mathrm{L}$, whereas $\mathrm{Sr}$ was extracted in higher amounts between 43 and $1013 \mu \mathrm{g} / \mathrm{L}$. Elements $\mathrm{Cd}, \mathrm{Hg}, \mathrm{Pb}$ and Co were not quantified in the extracts, because their concentration was below the instrument's detection limit (0.004-0.035 ppb). As stated above, although a direct comparison of current results with those of other investigations is not feasible, the findings are comparable, except those reported for $\mathrm{Pb}$ and $\mathrm{Cr}[10,12,19]$. For MSW fly ash, the concentration of $\mathrm{Pb}$ was found to exceed the legal limits in the leachates $34-86 \mathrm{mg} / \mathrm{L}[10,20,22]$ and that of $\mathrm{Cr}$ to be lower $0.24-0.41 \mathrm{mg} / \mathrm{L}[10,12]$, as opposed to present study, where $\mathrm{Pb}$ was not extracted at all, whereas $\mathrm{Cr}$ reached a hazardous level, about $30 \mathrm{mg} / \mathrm{L}$ (limit $1 \mathrm{mg} / \mathrm{L}$ ). Figure $2 \mathrm{~b}$ shows that the highest concentration was observed soon after the experiment was initialized and tended to decrease with time of leaching.

The reasons for the leachability behaviour of the trace elements of ash through the soil, can be found in the mineralogical and chemical composition of the solid materials involved, various reaction kinetics, the $\mathrm{pH}$ of solid and liquid phases, the permeability and CEC of soil, etc. [25,29]. Obviously, the highly alkaline nature of the ash attributed to basic $\mathrm{K}, \mathrm{Mg}$ and Ca-bearing minerals, which were partly dissolved in water raising the $\mathrm{pH}$ of the extracts, was a key factor for the low leachability of heavy metals. This is strengthened by the fact that the CEC of the soil was very low for adsorbing these species. The low migration of $\mathrm{Ni}, \mathrm{Co}, \mathrm{Cu}, \mathrm{Zn}, \mathrm{Mn}$ and $\mathrm{As}$ reveals that these could be tied up in the crystal lattice of the minerals which were incorporated in the quarzitic soil rocks [24], or bound in aluminosilicates such as microcline, muscovite and clinochlore, or stable oxides such as quartz and srebrodolskite. Moreover, the null leachability of $\mathrm{Pb}$, which is known to have calcium or organic affinity [12,22], suggests that this element was converted during the tests to insoluble oxide, or was associated to insoluble phosphates. However, the high extraction rate of $\mathrm{Cr}$ and-to a lesser extent- $\mathrm{Sr}$ implies their potential association with organic matter, or salts dissolved in the water extracts [24,25,32]. 

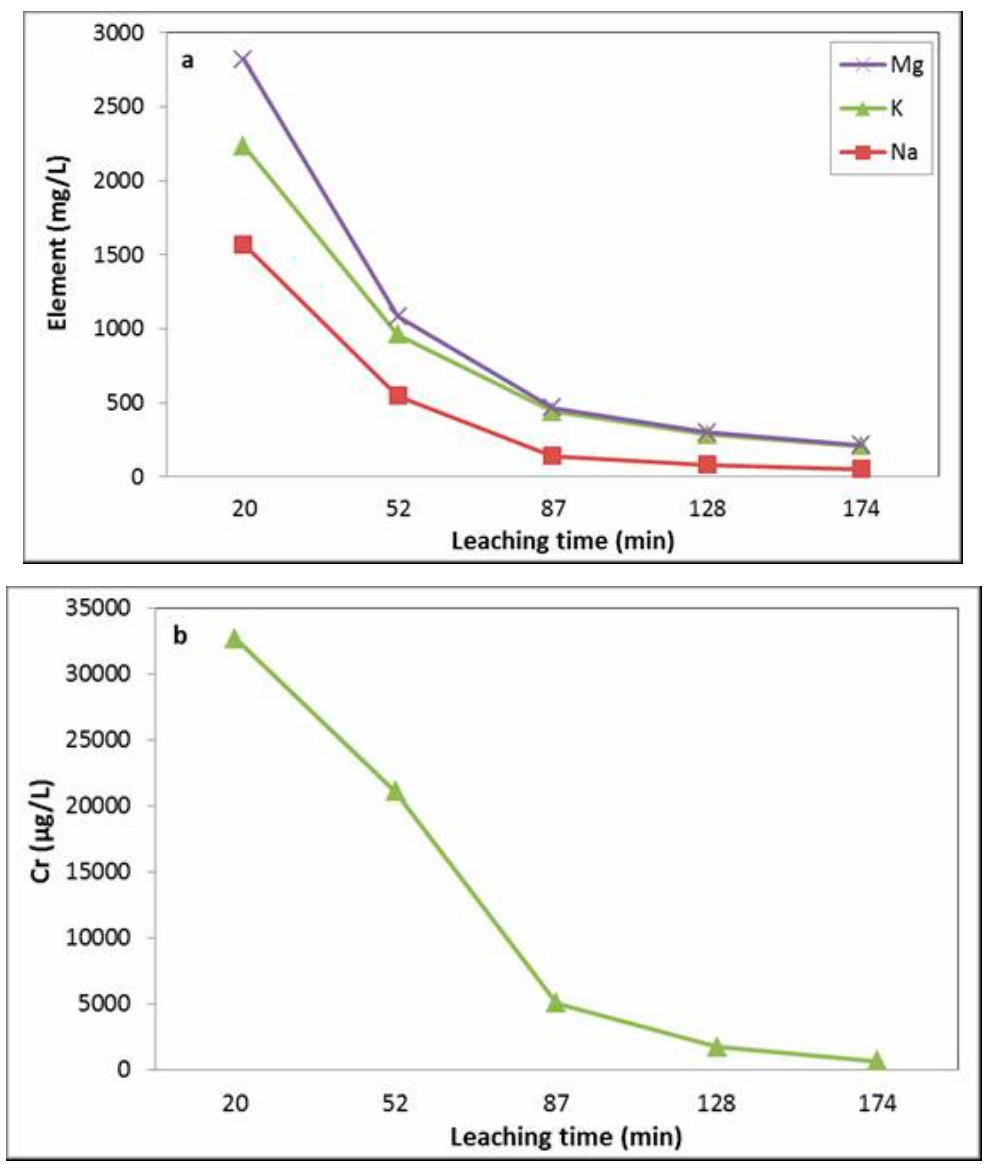

Figure 2. Variation of (a) alkali and (b) Cr concentration with leaching time from soil/unstabilized OK/MSW ash.

\subsection{Mineralogical and Chemical Properties of Stabilizers}

The XRD and chemical analysis results for the materials used in present study for the stabilization of OK/MSW ash are included and compared in Table 3 and Figure 3, respectively. Lignite fly ash was rich in quartz, hematite and mullite, wheat straw ash was rich in quartz, arcanite and calcite, whereas MBM biochar was rich in hydroxyapatite, whitlockite magnesian and calcium sodium phosphate. The high silicon content of silica fume is clearly shown in Figure 3, where the concentrations of the chemical elements reflect the mineral phases identified.

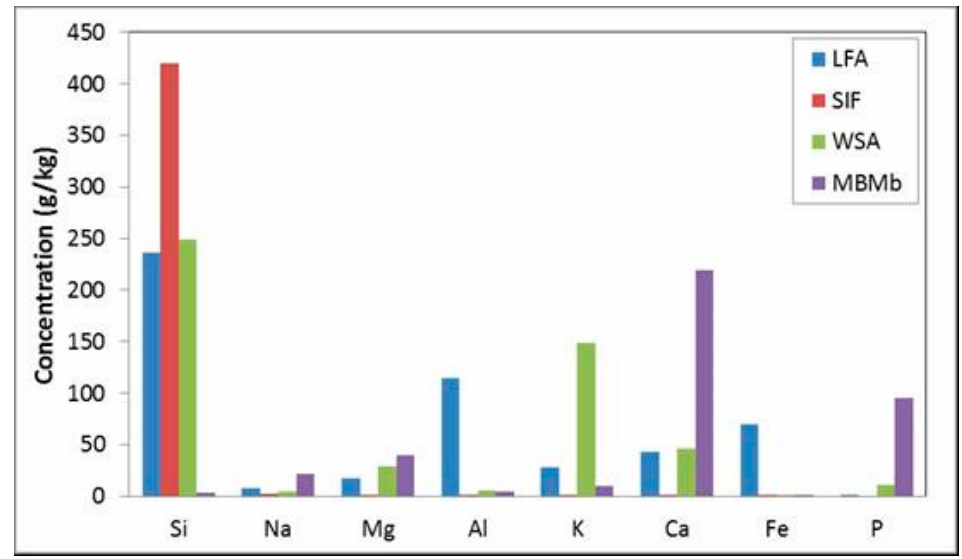

Figure 3. Chemical analysis of stabilizing materials lignite fly ash (LFA), silica fume (SIF), wheat straw ash (WSA) and meat and bone meal biochar $\left(\mathrm{MBM}_{\mathrm{b}}\right)$. 
Table 3. Mineralogical analysis of ash stabilizers.

\begin{tabular}{|c|c|c|c|c|}
\hline \multirow{2}{*}{ Mineral Phases } & \multicolumn{4}{|c|}{ Sample } \\
\hline & Lignite Fly Ash (LFA) & Silica Fume (SIF) & Wheat Straw Ash (WSA) & MBM Biochar $\left(\mathrm{MBM}_{\mathrm{b}}\right)$ \\
\hline Quartz $\mathrm{SiO}_{2}$ & +++ & & +++ & \\
\hline Calcite $\mathrm{CaCO}_{3}$ & + & & ++ & \\
\hline Albite $\mathrm{Na}\left(\mathrm{AlSi}_{3} \mathrm{O}_{8}\right)$ & & & + & \\
\hline Silicon $\mathrm{Si}$ & & +++ & & \\
\hline Moissanite SiC & & + & & \\
\hline Anhydrite $\mathrm{CaSO}_{4}$ & + & & + & \\
\hline Sylvite $\mathrm{KCl}$ & & & + & + \\
\hline Hydroxyapatite & & & & 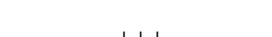 \\
\hline $\mathrm{Ca}_{5}\left(\mathrm{PO}_{4}\right)_{3}(\mathrm{OH})$ & & & + & +++ \\
\hline Hercynite $\mathrm{FeAl}_{2} \mathrm{O}_{4}$ & + & & & \\
\hline Hematite $\mathrm{Fe}_{2} \mathrm{O}_{3}$ & ++ & & & \\
\hline Mullite $\mathrm{Al}_{6} \mathrm{Si}_{2} \mathrm{O}_{13}$ & ++ & & & \\
\hline Orthoclase & & & & \\
\hline $\mathrm{KAlSi}_{3} \mathrm{O}_{8}$ & & & + & \\
\hline Anorthite (Ca, & ++ & & & \\
\hline $\begin{array}{l}\mathrm{Na}(\mathrm{Sl}, \mathrm{Al})_{4} \mathrm{O}_{8} \\
\text { Arcanite } \mathrm{K}_{2} \mathrm{SO}_{4}\end{array}$ & & & +++ & \\
\hline Calcium phosphate & & & & \\
\hline $\mathrm{NaCaPO}_{4}$ & & & & ++ \\
\hline Alite $\mathrm{NaCl}$ & & + & & \\
\hline Whitlockite & & & & \\
\hline magnesian & & & & + \\
\hline$(\mathrm{CaMg})_{3}\left(\mathrm{PO}_{4}\right)_{2}$ & & & & \\
\hline Fairchildite & & & 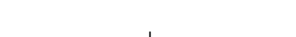 & \\
\hline $\mathrm{K}_{2} \mathrm{Ca}\left(\mathrm{CO}_{3}\right)_{2}$ & & & + & \\
\hline
\end{tabular}

\subsection{Leachability of the Various Species from the Soil/Stabilized Ash Samples}

Measurements of $\mathrm{pH}, \mathrm{EC}$, chloride and sulphate ions concentration in the leachates of OK/MSW ash, stabilized with $10 \% w / w$ lignite fly ash, or silica fume, or wheat straw ash, or MBM biochar as a function of time, are presented in Table 4 . In all cases $\mathrm{pH}$ increased with time of leaching from 7.3 to 8.8 , but not to the same extent as in the case of unstabilized ash (Table 2). This is attributed to the decreased dissolution of alkaline substances from the stabilized ash material, as all stabilizers, especially the fly ash, silica fume and MBM contained lower amounts of alkali, as previously shown (Table 3). Obviously, the $\mathrm{pH}$ of OK/MSW sample substituted by $30 \% w / w$ with stabilizers dropped, ranging from 7.5 to 8.2 in the liquid extracts. Slightly lower $\mathrm{pH}$ values were measured in the leachates collected from OK/MSW ash stabilized with $20 \%$ w/w of each stabilizer (results are not included in the table for economy reasons).

Table 4 shows that the EC of liquid samples was very low, similar to the values obtained from the unstabilized ash (Table 2) and decreased remarkably with time.

Concerning the concentrations of ions, it can be observed that there was a small increase actually of the sulphate ions, except for the ash stabilized with MBM biochar, as compared to the leachates from unstabilized ash (Table 2), due to the contribution of soluble anhydrite and arcanite from lignite fly ash and wheat straw ash stabilizers. MBM biochar did not contain any sulphate minerals (Table 3). The increase in sulphate ions is consistent with the lower $\mathrm{pH}$ values observed. Nevertheless, all values were much lower than the limits for non-hazardous waste landfills [30]. When stabilizers were added at a percentage of $20 \% w / w$ in OK/MSW ash, chlorine and sulphate ions were slightly increased.

The cumulative concentrations of major and trace elements leached from the OK/MSW ash stabilized with $10 \%$ or $20 \% w / w$ of lignite fly ash, silica fume, wheat straw ash and MBM biochar, according to the column leaching tests conducted, are compared in Table 5. The elements which showed very low $(<0.1 \%)$ or no extractability, such as $\mathrm{Al}(0-0.16 \%)$, Fe $(0-0.07 \%)$, Mn $(0-0.005 \%)$, $\mathrm{Ni}(0-0.1 \%), \mathrm{Zn}(0-0.07 \%), \mathrm{Cd}, \mathrm{Hg}, \mathrm{Pb}, \mathrm{Co}(0 \%)$, were not included in the table. As in the case of unstabilized ash, the concentrations ( $\mathrm{mg} / \mathrm{kg}$ ) of alkali and alkaline earth metals $\mathrm{Na}, \mathrm{K}, \mathrm{Ca}$ and $\mathrm{Mg}$ in the leachates were quite high. This was owned to the dissolution of soluble minerals in the forms of 
chlorides, sulphates and carbonates (Tables 1 and 3), present in these materials. However, Table 5 shows that the presence of all stabilizers in OK/MSW ash resulted in lower $\mathrm{Na}, \mathrm{K}$ and $\mathrm{Mg}$ contents in the leachates and decreased the relevant mass leached. Generally, Na presented the highest mobility among these elements, while $\mathrm{K}$ the lowest. It is interesting to note that, in the presence of MBM biochar, the amount of $\mathrm{Ca}$ and $\mathrm{Mg}$ elements in the leachates was significantly reduced. Such a behaviour could be assigned to the insoluble phosphates incorporating these elements in MBM biochar (Table 3), as well as its negative surface functional groups identified in the FTIR spectra shown below, which could act as retention sites. Moreover, addition of stabilizers to the OK/MSW ash at a percentage $20 \% w / w$ resulted in a further decrease in $\mathrm{Na}, \mathrm{K}$ and $\mathrm{Mg}$ in the water extracts. Overall, as compared to unstabilized ash, Na was reduced by $9-82 \%$, K by $73-99 \%$ and $\mathrm{Mg}$ by 3-97\%, when stabilizers were applied.

Table 4. Variation of $\mathrm{pH}, \mathrm{EC}$ and ions in the leachates of soil/ash with $10 \% w / w$ stabilizers.

\begin{tabular}{|c|c|c|c|c|c|}
\hline \multirow{2}{*}{ Soil/Ash/Stabilizer } & \multicolumn{5}{|c|}{ Leachate } \\
\hline & 1 & 2 & 3 & 4 & 5 \\
\hline \multicolumn{6}{|l|}{ LFA } \\
\hline $\mathrm{pH}$ & 7.74 & 7.86 & 8.17 & 8.37 & 8.43 \\
\hline $\mathrm{EC}(\mathrm{mS} / \mathrm{cm})$ & 2.8 & 1.6 & 0.75 & 0.39 & 0.23 \\
\hline $\mathrm{Cl}^{-}(\mathrm{mg} / \mathrm{L})$ & 53.2 & 16.2 & 9.1 & 8.5 & 6.9 \\
\hline $\mathrm{SO}_{4}{ }^{2-}(\mathrm{mg} / \mathrm{L})$ & 359 & 323 & 212 & 101 & 40 \\
\hline \multicolumn{6}{|l|}{ SIF } \\
\hline $\mathrm{pH}$ & 7.64 & 7.87 & 8.24 & 8.38 & 8.42 \\
\hline $\mathrm{EC}(\mathrm{mS} / \mathrm{cm})$ & 3.7 & 2.4 & 1.0 & 0.49 & 0.29 \\
\hline $\mathrm{Cl}^{-}(\mathrm{mg} / \mathrm{L})$ & 30.0 & 16.2 & 9.3 & 7.8 & 7.6 \\
\hline $\mathrm{SO}_{4}{ }^{2-}(\mathrm{mg} / \mathrm{L})$ & 447 & 162 & 59 & 50 & 47 \\
\hline \multicolumn{6}{|l|}{ WSA } \\
\hline $\mathrm{pH}$ & 8.02 & 8.69 & 8.73 & 8.75 & 8.81 \\
\hline $\mathrm{EC}(\mathrm{mS} / \mathrm{cm})$ & 4.1 & 1.5 & 0.63 & 0.57 & 0.45 \\
\hline $\mathrm{Cl}^{-}(\mathrm{mg} / \mathrm{L})$ & 44.7 & 9.1 & 8.4 & 8.0 & 7.7 \\
\hline $\mathrm{SO}_{4}{ }^{2-}(\mathrm{mg} / \mathrm{L})$ & 367 & 312 & 77 & 9 & 1 \\
\hline \multicolumn{6}{|l|}{$\mathrm{LFA}+\mathrm{SIF}+\mathrm{WSA}$} \\
\hline $\mathrm{pH}$ & 7.49 & 7.99 & 8.16 & 8.18 & 8.18 \\
\hline $\mathrm{EC}(\mathrm{mS} / \mathrm{cm})$ & 3.4 & 2.4 & 0.82 & 0.48 & 0.42 \\
\hline $\mathrm{Cl}^{-}(\mathrm{mg} / \mathrm{L})$ & 65.4 & 32.8 & 5.3 & 4.0 & 3.6 \\
\hline $\mathrm{SO}_{4}{ }^{2-}(\mathrm{mg} / \mathrm{L})$ & 361 & 332 & 91 & 45 & 12 \\
\hline \multicolumn{6}{|l|}{$\mathrm{MBM}_{\mathrm{b}}$} \\
\hline $\mathrm{pH}$ & 7.25 & 7.47 & 7.50 & 7.60 & 7.69 \\
\hline $\mathrm{EC}(\mathrm{mS} / \mathrm{cm})$ & 0.83 & 0.55 & 0.34 & 0.23 & 0.23 \\
\hline $\mathrm{Cl}^{-}(\mathrm{mg} / \mathrm{L})$ & 18.9 & 13.1 & 11.4 & 10.2 & 9.6 \\
\hline $\mathrm{SO}_{4}{ }^{2-}(\mathrm{mg} / \mathrm{L})$ & 200 & 183 & 121 & 88 & 72 \\
\hline
\end{tabular}

Table 5. Cumulative element concentrations and (\%) mass leached in the leachates with stabilizers.

\begin{tabular}{|c|c|c|c|c|c|c|c|c|}
\hline \multirow{2}{*}{ Sample } & \multicolumn{4}{|c|}{ Major Element Concentration (mg/kg) } & \multicolumn{4}{|c|}{ Trace Element Concentration $(\mu \mathrm{g} / \mathrm{kg})$} \\
\hline & $\mathrm{Na}$ & $\mathrm{Mg}$ & $\mathbf{K}$ & $\mathrm{Ca}$ & Sr & $\mathrm{Cr}$ & $\mathrm{Cu}$ & As \\
\hline \multirow{2}{*}{ Soil/ash } & 788.2 & 246.8 & 572.8 & 202.6 & 2272.5 & $20,232.1$ & 73.5 & 10.1 \\
\hline & $(65.7)$ & $(7.1)$ & $(6.3)$ & $(1.4)$ & $(3.5)$ & $(39.8)$ & $(0.2)$ & $(0.20$ \\
\hline \multirow{2}{*}{ Soil/ash $+10 \%$ LFA } & 298.0 & 65.8 & 20.8 & 75.5 & 660.5 & 5745.0 & 3.5 & \\
\hline & $(26.3)$ & (1.9) & $(0.2)$ & $(0.5)$ & $(1.1)$ & $(11.3)$ & $(-)$ & \\
\hline \multirow{2}{*}{ Soil/ash $+20 \%$ LFA } & 222.8 & 45.5 & 10.1 & 231.7 & 538.7 & 3137.0 & 11 & \\
\hline & (20.9) & $(1.4)$ & $(0.1)$ & $(1.7)$ & $(0.9)$ & (6.2) & - & - \\
\hline \multirow{2}{*}{ Soil/ash $+10 \%$ SIF } & 705.9 & 137.7 & 153.2 & 113.3 & 1243.9 & $11,342.8$ & 6.5 & \\
\hline & $(63.8)$ & $(4.1)$ & $(1.8)$ & $(0.8)$ & $(2.1)$ & $(22.4)$ & $(0.01)$ & - \\
\hline \multirow{2}{*}{ Soil/ash $+20 \%$ SIF } & 143.9 & 37.0 & 64.1 & 229.5 & 468.5 & 2219.3 & $100=1$ & \\
\hline & (14.2) & $(1.2)$ & $(0.8)$ & $(1.8)$ & $(0.9)$ & (4.4) & - & - \\
\hline \multirow{2}{*}{ Soil/ash + 10\% WSA } & 715.9 & 239.1 & 126.7 & 206.6 & 2064.7 & $14,064.3$ & 53.8 & 5.4 \\
\hline & $(64.0)$ & $(7.0)$ & $(1.4)$ & $(1.5)$ & $(3.4)$ & (27.7) & (0.1) & $(0.08)$ \\
\hline \multirow{2}{*}{ Soil/ash + 20\% WSA } & 281.9 & 104.6 & 10.0 & 489.1 & 848.7 & 4821.5 & 2.0 & \\
\hline & $(27.2)$ & $(3.0)$ & $(0.1)$ & $(3.0)$ & $(1.5)$ & $(9.5)$ & $(-)$ & - \\
\hline \multirow{2}{*}{$\begin{array}{l}\text { Soil/ash }+10 \% \text { LFA + } \\
10 \% \text { SIF }+10 \% \text { WSA }\end{array}$} & 340.6 & 82.1 & 6.9 & 394.4 & 760.9 & 4297.5 & 7.6 & \\
\hline & (35.6) & (2.5) & (0.09) & (3.1) & $(1.5)$ & $(8.5)$ & $(0.02)$ & - \\
\hline \multirow{2}{*}{ Soil/ash $+10 \% \mathrm{MBM}_{\mathrm{b}}$} & 281.3 & 46.0 & 47.5 & 72.1 & 395.5 & 2248.5 & - & \\
\hline & (23.5) & (1.3) & $(0.6)$ & $(0.5)$ & $(0.7)$ & $(4.4)$ & - & - \\
\hline \multirow{2}{*}{ Soil/ash $+20 \% \mathrm{MBM}_{\mathrm{b}}$} & 235.3 & 7.9 & 28.7 & 43.2 & 131.4 & 487.6 & - & - \\
\hline & (19.6) & $(0.2)$ & $(0.4)$ & $(0.3)$ & $(0.2)$ & $(0.9)$ & - & - \\
\hline
\end{tabular}


As concerns the heavy metals, Table 5 indicates that those which were extracted in higher amounts from OK/MSW ash were $\mathrm{Cr}(20.2 \mathrm{mg} / \mathrm{kg})$ and $\mathrm{Sr}(2.3 \mathrm{mg} / \mathrm{kg})$. The concentration of $\mathrm{Cu}$ in liquid effluents was $73.5 \mu \mathrm{g} / \mathrm{kg}$, while that of As $10.1 \mu \mathrm{g} / \mathrm{kg}$. Upon the addition of stabilizers, the concentrations of $\mathrm{Cr}$, $\mathrm{Sr}, \mathrm{Cu}$ and As were significantly reduced, as compared to the unstabilized ash and the reduction was further higher when the amount of stabilizer was increased. Thus, for $\mathrm{Cr}$ which presented the greater mobility the reduction was 30-98\%, for Sr 9-94\%, whereas for $\mathrm{Cu}$ and As it was $27-100 \%$ and $47-100 \%$, respectively. Measured values of heavy metals were within the limits stipulated by EU Directives [30,31], except for Cr. Although all stabilizers used were beneficial in diminishing heavy metal concentrations in water extracts, only MBM biochar decreased the leachability of toxic element $\mathrm{Cr}$ by $89-98 \%$, to below allowable limits for waste landfilling (for $20 \% w / w$ stabilizer, maximum concentration in leachates was $0.48 \mathrm{mg} / \mathrm{L}$, limit $1 \mathrm{mg} / \mathrm{L}$ ). Moreover, these results show that MBM biochar achieved the best performance in stabilizing OK/MSW ash.

Current findings cannot be directly compared with previous studies, due to different experimental set up and procedures and solid materials employed. Various investigations related to MSW fly ash stabilization with rice husk, silica fume and bottom MSW ash $[9,18,21,22]$ have reported the mitigation of heavy metals in the leachates, but only a few provided data relevant to hazardous limits. These studies used chemical stabilization methods with phosphoric acid [10] and sodium carbonate [12].

In order to investigate the mechanism behind the retention of the various metal species in the stabilized ash material, quantitative mineralogical analysis was conducted and the mineral phases are included in Table 6. The XRD spectra of all stabilized materials are illustrated in the Appendix A. It is known $[9,12]$ that solid residues containing $\mathrm{Ca}(\mathrm{OH})_{2}$ can promote the carbonation process and thus heavy metals immobilization, but this reaction requires several months to naturally occur (the ash studied was pretreated for 1 month). Furthermore, $\mathrm{Ca}(\mathrm{OH})_{2}$ can promote pozzolanic reactions with silica and alumina of solid wastes [20], forming calcium silicate hydrates or aluminum silicate hydrates, which can stabilize heavy metals. However, in this work, none of the raw materials contained $\mathrm{Ca}(\mathrm{OH})_{2}$. Even if it would have been formed during the stabilization procedure, the hydrates would have been detected in the XRD patterns, whereas $\mathrm{Ca}(\mathrm{OH})_{2}$ would have been consumed. On the contrary, our results show that crystalline $\mathrm{Ca}(\mathrm{OH})_{2}$ was identified in stabilized ash. Therefore, carbonation or pozzolanic reactions did not occur. As previously presented, upon addition of stabilizers to OK/MSW ash, the concentration of all metals studied in the leachates was significantly reduced, in some cases up to $100 \%$, despite the small drop of $\mathrm{pH}$ owned to sulphate ions. According to Table 6, the amount of $\mathrm{Si}$ in crystalline phases was lower in respect to $\mathrm{Si}$ of the raw materials and amorphous phase was high, between $36 \%$ and $45 \%$ in the case of silica fume. Amorphous silica, being reactive, most probably produced silanol groups during the stabilization process, which formed a weak acidic silica surface $[18,33]$. Protons from the silanol groups could be substituted by metal ions from the solution through cation exchange reactions, thus explaining the stabilization mechanism. These findings are supported by other studies, which used rice husk $[9,18,19]$, coal fly ash $[9,20]$, silica fume [17], flue gas desulphurization residue [9,18], or bottom ash [21], as amorphous silica source. Furthermore, the main differences between the XRD analysis of ash stabilized with lignite fly ash and wheat straw ash (Table 6) and the mineral phases of unstabilized ash (Table 1), are the new crystalline phases of stabilized materials hydrocalumite and zeophyllite, respectively. These silicates, apparently formed as a consequence of reactions occurring during the stabilization process, controlled the leaching of the various metals to some extent. Changes might also have occurred in the amorphous matrices, which did not involve crystalline phases.

Another reason, apart from the amorphous silica and the silicates formed during the stabilization procedure, for the practical null leachability of trace elements $\mathrm{Pb}, \mathrm{Mn}, \mathrm{Ni}, \mathrm{Zn}, \mathrm{Cu}$ and $\mathrm{As}$, can be assigned to the phosphates calcium sodium phosphate, whitlockite magnesian and hydroxyapatite, as indicated in Table 6. Past studies have shown that $\mathrm{Ca}$ in such phosphates can be typically substituted with cations with an ionic radius between 0.69 and $1.35 \AA$, to form insoluble phases [20]. This mechanism could explain the better performance of MBM biochar in retaining the above elements. Other mechanisms 
which have been proposed [34,35] include metals complexation, sorption, electrostatic attraction, competition between elements and precipitation. Finally, as concerns $\mathrm{Cr}$, its oxidation state could be negative under the alkaline conditions of the tests [36]. Thus, it could not neutralize the negative charge of hydroxides, carbonates, sulphates or silicates and form precipitates, which could explain its decreased immobilization.

The FTIR spectra of OK/MSW ash, stabilized with silica fume and MBM biochar (Figure 4), were selected to be presented here to support the immobilization mechanism proposed. The strong peaks at $478 \mathrm{~cm}^{-1}$ and $1113 \mathrm{~cm}^{-1}$ of ash with silica fume are assigned to Si-O and O-Si-O bonds [37]. The weak peaks between 446 and $796 \mathrm{~cm}^{-1}$ of both spectra are related to halocompounds, whereas the strong bands at 870,872 and $1434 \mathrm{~cm}^{-1}$ are related to $\mathrm{CO}_{3}{ }^{2-}$ vibration [17] from carbonates, as also identified by XRD analysis. When MBM biochar was used as a stabilizer, an intense absorption bond at $1010 \mathrm{~cm}^{-1}$ was detected, ascribed to $\mathrm{C}=\mathrm{C}$ or $\mathrm{C}-\mathrm{N}$ stretching vibration of alkenes and amines, respectively. Furthermore, in this case, the small intensity peak at $1610 \mathrm{~cm}^{-1}$ corresponded to $\mathrm{N}-\mathrm{H}$ bending from amines, or $\mathrm{C}=\mathrm{C}$ stretching from conjugated alkenes. The broad bands at $3406 \mathrm{~cm}^{-1}$ for MBM biochar and at 1406-1418 $\mathrm{cm}^{-1}$ for both materials indicate the presence of O-H groups, which for biochar were attributed to alcohol or carboxylic acid. In the spectra of OK/MSW ash, stabilized with silica fume, the absorption bond at $3416 \mathrm{~cm}^{-1}$ is assigned to stretching of $\mathrm{Si}-\mathrm{OH}$ vibration [37]. Finally, the small peaks at $2326 \mathrm{~cm}^{-1}$ and $2356 \mathrm{~cm}^{-1}$ are characteristic of $\mathrm{O}=\mathrm{C}=\mathrm{O}$ stretching. The results show that the surface of the materials was quite negatively charged, which could explain the bonding of cations observed.

Table 6. Quantitative mineralogical analysis of ash with $20 \% w / w$ stabilizers (\%).

\begin{tabular}{|c|c|c|c|c|c|}
\hline \multirow[b]{2}{*}{ Mineral Phases } & \multicolumn{5}{|c|}{ Sample } \\
\hline & Ash+LFA & $\mathrm{Ash}+\mathrm{SIF}$ & Ash+WSA & $\begin{array}{c}\text { Ash }+10 \% \text { LFA }+10 \% \text { SIF } \\
+10 \% \text { WSA }\end{array}$ & Ash $+\mathbf{M B M}_{\mathrm{b}}$ \\
\hline Amorphous & 36 & 45 & 39 & 41 & 37 \\
\hline Quartz $\mathrm{SiO}_{2}$ & 4 & & 3 & 3 & 3 \\
\hline Calcite $\mathrm{CaCO}_{3}$ & 18 & 16 & 16 & 15 & 17 \\
\hline Srebrodolskite $\mathrm{Ca}_{2} \mathrm{Fe}_{2} \mathrm{O}_{5}$ & 10 & 10 & 8 & 6 & 8 \\
\hline Silicon $\mathrm{Si}$ & & 3 & & 2 & \\
\hline Moissanite SiC & & 3 & & & \\
\hline Anhydrite $\mathrm{CaSO}_{4}$ & 3 & 2 & 3 & 2 & 1 \\
\hline Sylvite $\mathrm{KCl}$ & & & & & 1 \\
\hline Hydroxyapatite & 3 & & & & 10 \\
\hline $\mathrm{Ca}_{5}\left(\mathrm{PO}_{4}\right)_{3}(\mathrm{OH})$ & 3 & 3 & 4 & 3 & 10 \\
\hline Hydrocalumite & 3 & & & & \\
\hline $\mathrm{Ca}_{4} \mathrm{Al}_{2}(\mathrm{OH})_{12}\left(\mathrm{Cl}, \mathrm{CO}_{3}, \mathrm{OH}\right)_{2} \cdot 4 \mathrm{H}_{2} \mathrm{O}$ & 3 & & & & \\
\hline Mascagnite $\left(\mathrm{NH}_{4}\right)_{2} \mathrm{SO}_{4}$ & & & 7 & 6 & \\
\hline Mullite $\mathrm{Al}_{6} \mathrm{Si}_{2} \mathrm{O}_{13}$ & 5 & & & & \\
\hline Microcline $\mathrm{KAlSi}_{3} \mathrm{O}_{8}$ & & & & 3 & 3 \\
\hline Monticellite $\mathrm{Ca}(\mathrm{MgFe}) \mathrm{SiO}_{4}$ & 3 & 2 & 3 & 3 & 1 \\
\hline Arcanite $\mathrm{K}_{2} \mathrm{SO}_{4}$ & 7 & 7 & 7 & 7 & 7 \\
\hline Periclase $\mathrm{MgO}$ & 2 & 2 & & & \\
\hline Portlandite $\mathrm{Ca}(\mathrm{OH})_{2}$ & 3 & 2 & 3 & 3 & 1 \\
\hline Aphthitalite $\mathrm{NaK}_{3}\left(\mathrm{SO}_{4}\right)_{2}$ & & & & & 2 \\
\hline Zeophyllite & & & 4 & & \\
\hline $\mathrm{Ca}_{13} \mathrm{Si}_{10} \mathrm{O}_{28}(\mathrm{OH})_{2} \mathrm{~F}_{8} \cdot 6 \mathrm{H}_{2} \mathrm{O}$ & & & 4 & 2 & \\
\hline Biphosammite $\mathrm{NH}_{4} \mathrm{H}_{2} \mathrm{PO}_{4}$ & & & & 2 & \\
\hline Alite $\mathrm{NaCl}$ & & 2 & & & \\
\hline $\begin{array}{l}\text { Whitlockite magnesian } \\
\qquad(\mathrm{CaMg})_{3}\left(\mathrm{PO}_{4}\right)_{2}\end{array}$ & & & & & 8 \\
\hline Fairchildite $\mathrm{K}_{2} \mathrm{Ca}\left(\mathrm{CO}_{3}\right)_{2}$ & 3 & 3 & 3 & 2 & 1 \\
\hline
\end{tabular}



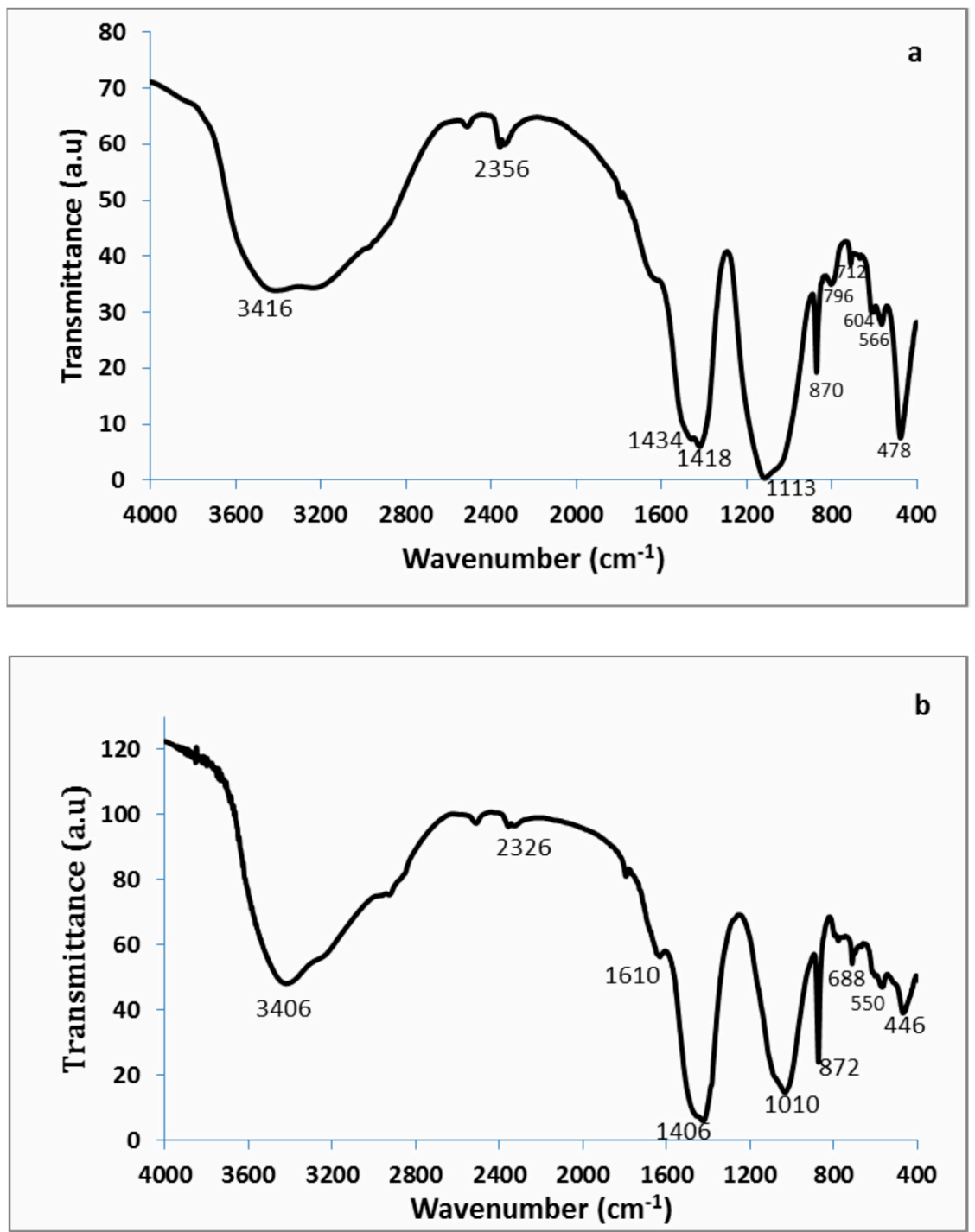

Figure 4. FTIR spectra of OK/MSW ash stabilized with (a) silica fume (SIF) and (b) meat and bone meal biochar $\left(\mathrm{MBM}_{\mathrm{b}}\right)$.

\section{Conclusions}

When OK/MSW ash was leached through a soil of quarzitic nature and low cation exchange capacity, alkaline compounds of $\mathrm{K}, \mathrm{Mg}$ and Ca were partially dissolved in water extracts, increasing their $\mathrm{pH}$ from $\sim 8$ to 9 and thus decreasing the leachability of heavy metals from the ash. The low mobility of these elements was also attributed to the mineralogical and chemical composition of the solid materials involved. Only $\mathrm{Cr}$ reached a hazardous level in the leachates for wastes disposal in landfills. The concentrations of chlorine and phosphate ions in the extracts were very low, while that of sulphate ions was significant.

When OK/MSW ash was stabilized with waste materials lignite fly ash, silica fume, wheat straw ash or MBM biochar, the extractability of alkali metals $\mathrm{Na}, \mathrm{K}$ and $\mathrm{Mg}$ was lowered by $3 \%$ to $99 \%$ and the concentration of sulphate ions in the leachates was somehow increased, both resulting in a small drop of $\mathrm{pH}$, which varied between 7.3 and 8.8. Moreover, upon addition of stabilizers to the ash, the leachability of trace elements $\mathrm{Mn}, \mathrm{Ni}, \mathrm{Zn}$ and $\mathrm{Pb}$ was practically null, whereas the levels of $\mathrm{Cu}$, Sr, As and $\mathrm{Cr}$ in the extracts were significantly reduced by $27-100 \%, 9-94 \%, 47-100 \%$ and $30-98 \%$, respectively. MBM biochar achieved the best performance as stabilizer, being also the only one to decrease the mobility of $\mathrm{Cr}$ to values below allowable limits. The mechanisms for elements entrapment 
were assigned to the amorphous silica and phosphates present in the stabilizing materials, the surface functional groups, as well as complexed silicates formed during the stabilization process.

Overall, present study proposes a method for the safe management of ashes generated from agricultural and municipal solid wastes, through valorization of other waste materials, avoiding the use of chemicals. Stabilized ash could be used for the remediation of heavy metals in landfills or for application in other fields, such as the construction of materials, thus offering economic and environmental benefits.

Author Contributions: Conceptualization, D.V.; methodology, D.V.; software, G.A. and A.S.; validation, D.V. and S.A.; formal analysis, D.V.; investigation, D.V. and S.A.; resources, S.A.; data curation, S.A.; writing-original draft preparation, D.V.; writing - review and editing, D.V.; visualization, D.V.; supervision, D.V. All authors have read and agreed to the published version of the manuscript.

Funding: This research received no external funding.

Acknowledgments: The authors kindly thank the laboratories of Hydrogeochemical Engineering and Soil Remediation, Management of mining/metallurgical wastes and Hydrocarbons Chemistry and Technology of the Technical University of Crete, for the ICP-MS, UV-VIS and FTIR analyses.

Conflicts of Interest: The authors declare no conflict of interest.

\section{Appendix A}

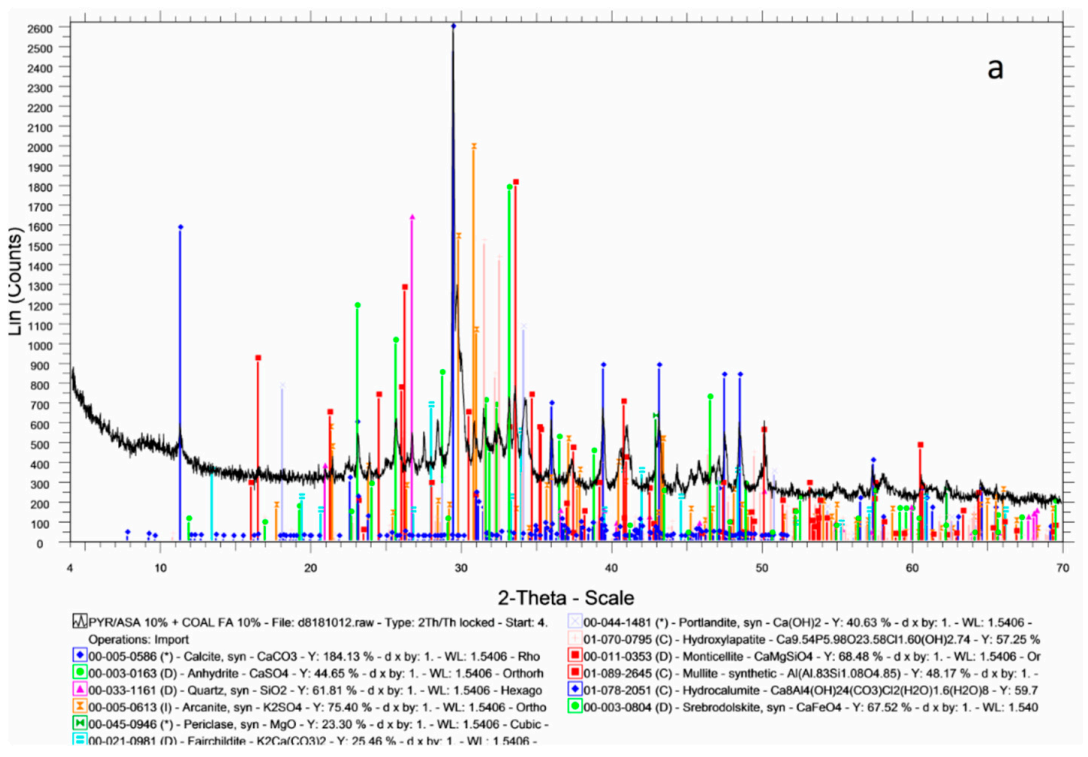

Figure A1. Cont. 

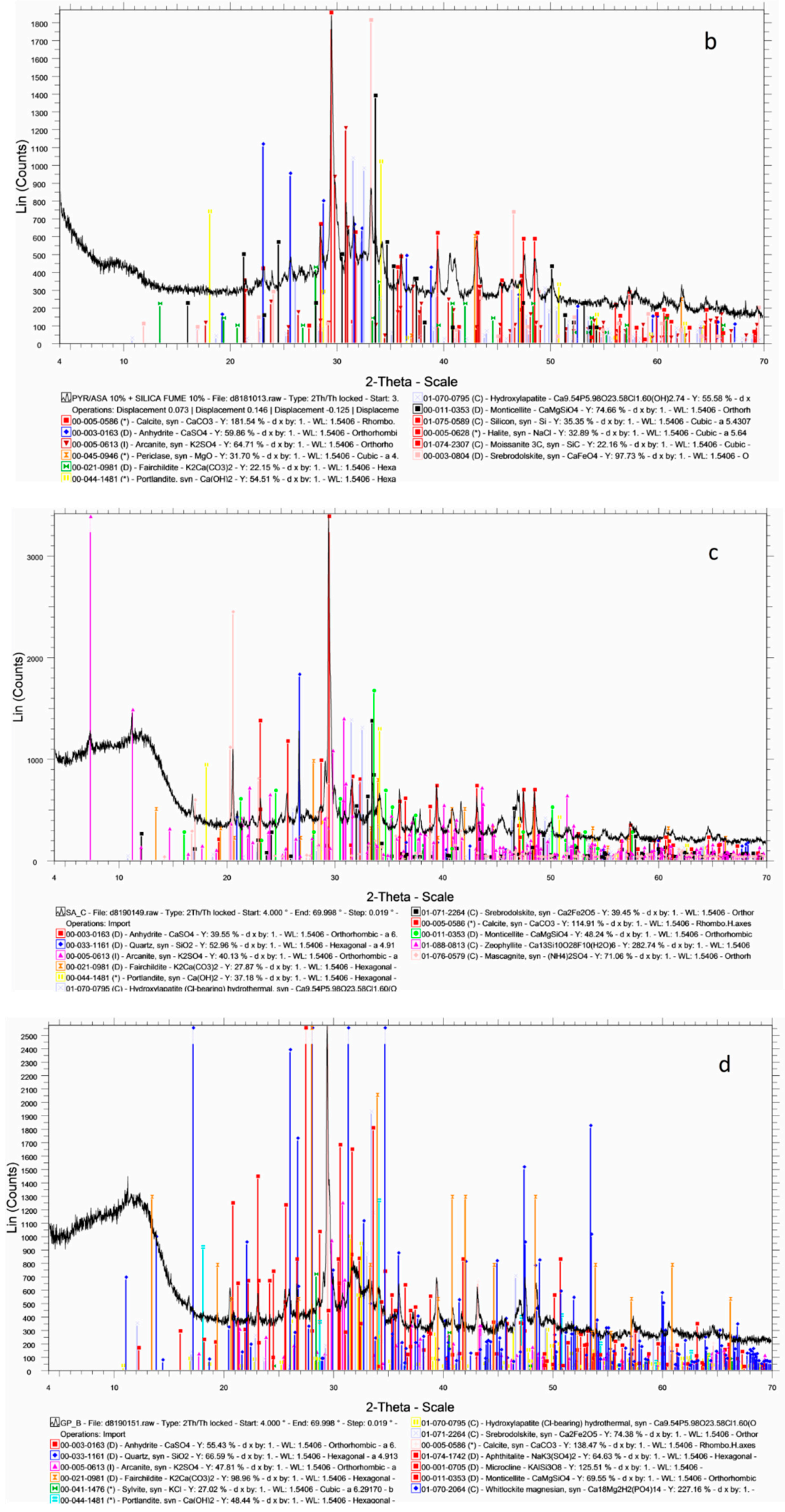

Figure A1. XRD spectra of stabilizing materials (a) lignite fly ash (LFA), (b) silica fume (SIF), (c) wheat straw ash (WSA) and (d) meat and bone meal biochar $\left(\mathrm{MBM}_{\mathrm{b}}\right)$. 


\section{References}

1. Directive 2009/28/EC of the European Parliament and of the Council of 23 April 2009. Promotion of the use of energy from renewable sources and amending and subsequently repealing Directives 2001/77/EC and 2003/30/EC. Off J. 140 (05/06/2009) 0016-62, 2009.

2. Vamvuka, D.; Sfakiotakis, S.; Mpoumpouris, A. Slagging and fouling propensities of ashes from urban and industrial wastes. Recen. Innov. Chem. Eng. 2018, 11, 145. [CrossRef]

3. Sfakiotakis, S.; Vamvuka, D.; Kosmadaki, M. Combustion characteristics and thermal behaviour of agricultural/urban waste blends as potential feedstocks for energy production. In Proceedings of the 6th Int. Conference on Hazardous and Industrial Waste Management, Chania-Crete, Greece, 4-7 September 2018.

4. Van Caneghem, J.; Brems, A.; Lievens, P.; Block, C.; Billen, P.; Vermeulen, I. Fluidized bed waste incinerators: Design, operational and environmental issues. Prog. Energy Combust. Sci. 2012, 38, 551. [CrossRef]

5. Siddique, R. Utilization of wood ash in concrete manufacturing. Resour. Conserv. Recycl. 2012, 67, 27. [CrossRef]

6. Garcia-Maraver, A.; Mata-Sanchez, J.; Carpio, M.; Perez-Jimenez, J. Critical review of predictive coefficients for biomass ash deposition tendency. J. Energy Inst. 2017, 90, 214. [CrossRef]

7. Steenari, B.M.; Lindqvist, O. Stabilisation of biofuel ashs for recycling to forest soil. Biomass Bioenergy 1997, 13, 39. [CrossRef]

8. Adriano, D.C. Trace Elements in Terrestrial Environments. Biogeochemistry, Bioavailability and Risks of Metals; Springer: New York, NY, USA, 2001.

9. Bosio, A.; Zacco, A.; Borgese, I.; Rodella, N.; Colombi, P.; Benassi, L.; Depero, L.E.; Bontempi, E. A sustainable technology for $\mathrm{Pb}$ and $\mathrm{Zn}$ stabilization based on the use of only waste materials: A green chemistry approach to avoid chemicals and promote $\mathrm{CO}_{2}$ sequestration. Chem. Eng. J. 2014, 253, 377. [CrossRef]

10. Vanna, C.; Voutsas, E.; Magoulas, K. Process development for chemical stabilization of fly ash from municipal solid waste incineration. Chem. Eng. Res. Des. 2017, 125, 57.

11. Wang, H.; Fan, X.; Wang, Y.; Li, W.; Sun, Y.; Zhan, M.; Wu, G. Comparative leaching of six toxic metals from raw and chemically stabilized MSWI fly ash using citric acid. J. Environ. Manag. 2018, 208, 15. [CrossRef]

12. Atanes, E.; Cuesta-Garcia, B.; Nieto-Marquez, A.; Fernandez-Martinez, F. A mixed separation-immobilization method for soluble salts removal and stabilization of heavy metals in municipal solid waste incineration fly ash. J. Environ. Manag. 2019, 240, 359. [CrossRef]

13. Li, R.; Zhang, B.; Wang, Y.; Zhao, Y.; Li, F. Leaching potential of stabilized fly ash from the incineration of municipal solid waste with a new polymer. J. Environ. Manag. 2019, 232, 286. [CrossRef]

14. Xie, K.; Hu, H.; Xu, S.; Chen, T.; Huang, Y.; Yang, Y.; Yang, F.; Yao, H. Fate of heavy metals during molten salts thermal treatment of municipal solid waste incineration fly ashes. Waste Manag. 2010, 103, 334. [CrossRef] [PubMed]

15. Zhao, Y.; Song, L.; Li, G. Chemical stabilization of MSW incinerator fly ashes. J. Hazard. Mater. 2002, 95, 47.

16. Zhang, B.; Zhou, W.; Zhao, H.; Tian, Z.; Li, F.; Wu, Y. Stabilization/solidification of lead in MSWI fly ash with mercapto functionalized dendrimer. Chelator. Waste Manag. 2016, 50, 105. [CrossRef] [PubMed]

17. Rodella, N.; Bosio, A.; Zacco, A.; Borgese, L.; Pasquali, M.; Dalipi, R.; Depero, L.E.; Patel, V.; Bingham, P.A.; Bontempi, B. Arsenic stabilization in coal fly ash through the employment of waste materials. J. Environ. Chem. Eng. 2014, 2, 1352. [CrossRef]

18. Benassi, L.; Bosio, A.; Dalipi, R.; Borgese, L.; Rodella, N.; Pasquali, M.; Depero, L.E.; Bergese, P.; Bontempi, E. Comparison between rice husk grown in different regions for stabilizing fly ash from a solid waste incinerator. J. Environ. Manag. 2015, 159, 128. [CrossRef]

19. Chiu, A.; Akesseh, R.; Moumouni, I.; Xiao, Y. Laboratory assessment of rice husk ash (RHA) in the solidification/stabilization of heavy metal contaminated slurry. J. Hazard. Mater. 2019, 371, 62. [CrossRef]

20. Benassi, L.; Zanoletti, A.; Depero, L.; Bontempi, E. Sewage sludge ash recovery as valuable raw material for chemical stabilization of leachable heavy metals. J. Environ. Manag. 2019, 245, 464. [CrossRef]

21. Assi, A.; Bilo, F.; Zanoletti, A.; Ponti, J.; Valsesia, A.; La Spina, R.; Zacco, A.; Bontempi, E. Zero-waste approach in municipal solid waste incineration: Reuse of bottom ash to stabilize fly ash. J. Clean. Prod. 2020, 245, 118779. [CrossRef] 
22. Liu, Z.; Yue, Y.; Lu, M.; Zhang, J.; Sun, F.; Huang, X.; Zhou, J.; Qian, G. Comprehension of heavy metal stability in municipal solid waste incineration fly ash with its compositional variety: A quick prediction case of leaching potential. Waste Manag. 2019, 84, 329. [CrossRef]

23. Alexandrakis, S. Environmental Pollution of Soils from Deposition of Ashes Produced by Co-Combustion of Urban and Agricultural Wastes of Chania Region in Crete. Master's Thesis, Technical University of Crete, Chania, Greece, 2019.

24. Vamvuka, D.; Kaniadakis, G.; Pentari, D.; Alevizos, G. Comparison of ashes from fixed/fluidized bed combustion of swine sludge and olive by-products. Properties, environmental impact and potential uses. Renew. Energy 2017, 112, 74. [CrossRef]

25. Vamvuka, D.; Sfakiotakis, S.; Pantelaki, O. Evaluation of gaseous and solid products from the pyrolysis of waste biomass blends for energetic and environmental applications. Fuel 2019, 236, 574. [CrossRef]

26. Sumner, M.E.; Miller, W.P. Cation exchange capacity and exchange coefficients. In Methods of Soil Analysis. Part 3. Chemical Methods; Bingham, J.M., Ed.; ASA-SSSA Madison: Madison, WI, USA, 1996.

27. Vassilev, S.V.; Baxter, D.; Andersen, L.K.; Vassileva, C.G. An overview of the composition and application of biomass ash. Part 1. Phase-mineral and chemical composition and classification. Fuel 2013, 105, 40. [CrossRef]

28. Decision 2018/853 of the European Parliament and the Council as regards procedural rules in the field of environmental reporting and repealing Council Directive 91/692/EEC. 2018.

29. Gondek, K.; Mierzwa-Hersztek, M.; Kopec, M. Mobility of heavy metals in sandy soil after application of composts produced from maize straw, sewage sludge and biochar. J. Environ. Manag. 2018, 210, 87. [CrossRef] [PubMed]

30. Council of the European Union. Council decision 2003/33/EC of 19 December 2002 establishing criteria and procedures for the acceptance of waste at landfills pursuant to Article 16 of and Annex II to Directive 1999/31/EC. Off. J. European Commun. L11 (16/01/2003) 27, 2003.

31. EU Commission Decision. 2014/955/EU Amending Decision 2000/532/EC on the List of Waste Pursuant to Directive 2008/98/EC of the European Parliament and the Council; Official J. of the EU: Brussels, Belgium, 2014.

32. Vamvuka, D.; Trikouvertis, M.; Pentari, D.; Alevizos, G.; Stratakis, A. Characterization and evaluation of fly and bottom ashes from combustion of residues from vineyards and processing industry. J. Energy Inst. 2017, 90, 574. [CrossRef]

33. Rodriguez, E.T.; Garbev, K.; Merz, D.; Black, I.; Richardson, I.G. Thermal stability of C-S-H phases and applicability of Richardson and Groves' and Richardson C-(A)-S-H(I) models to synthetic C-S-H. Cem. Concr. Res. 2017, 93, 45. [CrossRef]

34. Shaaban, M.; Van Zwieten, L.; Bashir, S.; Younas, A.; Núñez-Delgado, A.; Chhajro, M.A.; Kubar, K.A.; Ali, U.; Rana, M.S.; Mehmood, M.A.; et al. A concise review of biochar application to agricultural soils to improve soil conditions and fight pollution. J. Environ. Manag. 2018, 228, 429. [CrossRef]

35. Boostani, H.; Najafi-Ghiri, M.; Hardie, A.; Khalili, D. Comparison of Pb stabilization in a contaminated calcareous soil by application of vermicompost and sheep manure and their biochars produced at two temperatures. Appl. Geochem. 2019, 102, 121. [CrossRef]

36. Chen, Q.; Tyrer, M.; Hills, C.; Yang, X.; Carey, P. Immobilization of heavy metal in cement-based solidification/stabilization: A review. Waste Manag. 2009, 29, 390. [CrossRef]

37. Qian, L.; Ma, M. The decreased release of heavy metals from fly ashes by adding alunite. J. Molec. Liq. 2014, 198, 323. [CrossRef]

(C) 2020 by the authors. Licensee MDPI, Basel, Switzerland. This article is an open access article distributed under the terms and conditions of the Creative Commons Attribution (CC BY) license (http://creativecommons.org/licenses/by/4.0/). 